\title{
INTEGRATED FARMING SYSTEMS (IFS) - A REVIEW PAPER
}

\author{
Aman Kumar Gupta ${ }^{1}$, Dipak Yadav ${ }^{1}$, Blaise Gaurav Dungdung ${ }^{2}$, Jiwan Paudel ${ }^{3}$, Avdhesh Kumar Chaudhary ${ }^{1}$, \\ Rehan Arshad ${ }^{1}$ \\ ${ }^{1}$ (IAS, Banaras Hindu University, Varanasi-221005, U.P., India) \\ ${ }^{2}$ (Centre for Geospatial Technologies, SHUATS, Prayagraj-211007 U.P., India) \\ ${ }^{3}$ (Rajiv Gandhi South Campus, Banaras Hindu University, Barkachha, Mirzapur 231001, U.P., India)
}

\begin{abstract}
Integrated farming systems (IFS) is an ecofriendly approach in which waste of one enterprise becomes the input of another thus its make more efficient use of resources from the farm. IFS as a mixed farming system that consists of at least two separate but logically interdependent parts of a crop and livestock enterprises. IFS helps in improving the soil health, weed and pest control, increase water use efficiency and maintains water quality. In integrated farming system the use of harmful chemical fertilizers, weed killers and pesticides should be minimized and also provide safeguards to the environment from the adverse effects. Integrated farming system improves economic condition of the small and marginal farmers which enhanced the education, health and social obligations and overall improvement in livelihood security. Though IFS approach the use of chemicals (fertilizers and pesticides) can be reduced to provide chemical free healthy food to the society.
\end{abstract}

Keywords - Integrated Farming System, Concept, Goals, Components and Advantages

\section{INTRODUCTION}

According to the Economic Survey of India, in 2008, the growth rate of food grain production decelerated to $1.2 \%$ during 1990-2007, that is lower than the population growth of $1.9 \%$. It is estimated that in our country population will touch 1370 million by 2030 and to 1600 million by 2050 . To meet the demand for future, we have to produce 289 and $349 \mathrm{mt}$ of food grains during the respective periods. The current scenario in the country indicates that area under cultivation may further decrease and more than $20 \%$ of current cultivable area will be converted into non-agricultural purposes by 2030 (Gill et al., 2005). In India shrinking average farm size and financial constraints for higher investment in agriculture due to $80 \%$ of the farm families are belonging to small and marginal farmer categories further heighten the challenge. For securing nutrition and food security for massive population, productivity enhancement may provide a vital solution. This involves in adoption of scientific agronomic practices and technologies which pact an augmentation of the productive capacity of conventional agricultural systems. Agronomic practices such as the permissive use of inorganic fertilizers and pesticides during the $20^{\text {th }}$ century enhanced productivity significantly but undesirable environmental degradation accompanied by increased operational costs in agriculture raised concerns about economic feasibility and sustainability (IAASTD, 2009 and FAO, 2010). In the past, animals were used directly for food or to provide other services such as power (draught animals) or transportation (horses) in integrated farming systems. In addition, animals were employed indirectly to provide services such as weed and pest control, fertilization, or pollination; or food items such as milk, eggs or honey. Animals were also a source of materials such as manure or leather that could be sold directly or converted to a value-add product, returning cash to the enterprise (Devendra and Thomas, 2002).

Environmental pollutions are done through unsustainable farming and threatens the livelihood of millions of small farm holders families. Increasing agricultural production systems for greater sustainability and higher economic returns is a critical process for increasing income, food and nutrition security in developing countries (Ravallion, 2007). IFS is an integrative whole farm approach and effective in solving the problems of small and marginal farmers. Aim of IFS is boosting employment and income from small-holding by integrating various farm enterprises and recycling crop residues and by products within the farm itself. The farmers need to be settled of regular income for living at least above poverty line. The progress in production or steady growth in output is necessary to face the challenges posed by present economic, political and technological environment. In this context, farming system approach is one of the important solutions to face this peculiar situation as in this approach the different enterprises can be carefully undertaken and the location specific systems are developed based on available resources which will result into sustainable development (Dashora and Hari, 2014) In IFS system a linked set of enterprises used so that the "waste" from one component becomes an input for another part of the system, which helps in reducing cost and improving the production or income of farmers. IFS provide that wastes from one form of agriculture become a resource for another form. Since it utilizes wastes as 


\section{International Journal of Engineering Applied Sciences and Technology, 2020 \\ Vol. 4, Issue 9, ISSN No. 2455-2143, Pages 134-137 \\ Published Online January 2020 in IJEAST (http://www.ijeast.com)}

resources, we not only eliminate wastes but we also secure overall increase in productivity for the whole agricultural systems (CARDI, 2010) IFS consists of a range of resourcesaving practices that aim to achieve acceptable profits and high and sustained production levels, while minimizing the negative effects of comprehensive farming and maintaining the environmental conditions (Lal and Miller, 1990; Gupta et al., 2012).

\section{CONCEPTS OF IFS}

IFS as a mixed farming system that consists of at least two separate but logically interdependent parts of a crop and livestock enterprises defined by (Okigbo, 1995). (Edwards, 1997 and Jitsanguan, 2001) defined the IFS as an aquaculture system that is integrated with animals and in which fresh animal waste is used to feed fish and also reported that there are synergies and complementarity between enterprises that comprise a crop and animal factor that form the basis of the concept of IFS. Farming arrangement is a mix of farm enterprises in which farm holders designate resources for efficient utilization of the actual enterprises for increasing productivity and profitability of the farm. These farm enterprises are crop, agro-forestry, livestock, aquaculture, agri-horticulture and sericulture (Singh, 2004). (Radhamani et al., 2003) explain IFS as a component of farming systems which takes into account the concepts of increasing production, minimizing risk and profits whilst improving the utilization of organic wastes and crop residues of the field. (Jayanthi, 2006) defined that IFS is a component of FRS (Farming System Research), introduces a transformation in the farming techniques for increasing production in the cropping pattern and takes care of excellent utilization of resources. (Panke et al., 2010) stated that the integration is made in such a way that the product i.e. output of one enterprise / component should be the input for the other enterprises with high degree of complementarity effects. Similarly the authors stated that the rationale of IFS is to minimize the wastes from the various sub systems on the farm and thus it improves employment opportunities, nutritional security and income of the rural people.

\section{GOALS OF INTEGRATED FARMING SYSTEM}

The four primary goals of IFS are-

1. Maximization of the yield of all component enterprises to provide steady and stable income.

2. Rejuvenation/amelioration of the system's productivity and achieve agro-ecological equilibrium.

3. Avoid the build-up of insect-pests, diseases and weed populations through natural cropping system management and keep them at a low level of intensity.

4. Reducing the use of chemicals (fertilizers and pesticides) to provide chemical-free healthy produce and environment to the society (Manjunatha, 2014).

\section{COMPONENTS OF IFS}

(Thamizoli et al., 2006) found that the introduction of forestry with agriculture along with the farm-based allied enterprises like dairy, apiculture, goat rearing, etc. as a risk management strategy to cope up with disasters like long drought season and heavy flood. (Mohanty et al., 2010) determine the IFS model subsist of field crops (Rice, groundnut, maize, pigeon, pea and ragi), horticultural crops (Yam, banana, tapioca, and vegetables), poultry (Vanaraja breed) and vermicomposting in Gajapati district of Orissa. (Tripathi and Rathi, 2011) describes that various current farming system models in Uttarkhand namely., crop + dairy, crop + dairy + goats + horticulture, crop + horticulture +goats, crop +dairy + vegetables, dairy + vegetables + horticulture, dairy + vegetables and dairy + crop + companion animals are the major components in IFS. (Manivannan et al., 2011) described that the prisoner from Erode district of Tamilnadu were having goat +crop, goat +dairy + crop, goat + dairy and goat +dairy +crop systems as the main components in IFS. Components of IFS include - A. Agriculture - Horticulture, Forestry, Dairy, Fish farming, Duck rearing. B. Mushroom cultivation Sericulture, Azolla farming, Kitchen gardening, Fodder production, Nursery. C. Seed Production- Vermiculture, Pigeon rearing, Apiary, Goat rearing, Poultry. D. Sheep rearing- Piggery, Rabbitry, Value addition (Lal et al., 2018). An integrated approach unique to small-scale farms is the increasingly popular practice of aquaponics. Typically associated with greenhouse or other controlled environment production systems, aquaponics is the combination of fish culture (aquaculture) and soilless plant production (hydroponics). In this type of production system, nutrients derived from fish waste, with tilapia being the most common fish species used, are recirculated through the system and utilized by plants to meet their nutrient requirements. Typically, large amount of fish are raised in small volumes of water to allow an aggregation of non-toxic nutrient concentrations (Rakocy et al., 2006).

\section{ADVANTAGES}

IFS it is more advantageous than the farmers can able to produce more by using optimal resource utilization and recycling waste materials and family labor employment. It helps to any investigation, as it not only gives an idea of the work done in the past but also provides a basis for interpretation and discussion of the findings for the future research investigation (Sasikala et al., 2015). (Ngambeki et $a l .$, 1992) demonstrated the profitability of the system by integrating livestock into crop-based farming through increased financial benefits and better use of intermediate farm resources such as manure, draft power, and crop residues. (Singh et al., 1993 and Singh et al., 1997) observed that the integration of various enterprises on various sizes of land holdings tend to be more profitable than arable farming 


\section{International Journal of Engineering Applied Sciences and Technology, 2020 \\ Vol. 4, Issue 9, ISSN No. 2455-2143, Pages 134-137 \\ Published Online January 2020 in IJEAST (http://www.ijeast.com)}

alone, and generate more employment. (Rangasamy et al., 1996) describes the integration of poultry, mushroom and fish with rice cultivation over five years boost the net farm income and on-farm labor when compared with the conventional rice cropping system and also the comparative analysis suggested that diversification and integration of resource management can be productive, profitable and manageable, given access to labor and secure tenure.

(Ashby, 2001) indicated that the reliance upon a few crops in combination with a high risk of crop failure due to a range of factors like disease, drought, etc. exposes farmers to a high degree of variability concerning yields and income and therefore risk. Animal manure is a valuable fertilizer as well, conferring inputs to the soil over and above the simple chemical nutrients of $\mathrm{N}, \mathrm{P}$ and $\mathrm{K}$. As an input into the crop cultivation systems, manure continues to be the link between crop and animal production throughout the developing world. The great challenge is to develop better ways of increasing the benefits to society and to the environment that manure can bring (Tania, 1996). Crop residues can be used for feeding to animal, while enhancing the agricultural productivity should be done through utilization of manure from livestock by intensifying nutrients that improve soil fertility as well as reducing the use of chemical fertilizers (Gupta et al ., 2012). Greater sustainability in production on farms due to the integration of diverse enterprises of different economic importance. Recycling of wastes being built in the system helps to reduce dependence on external high-energy inputs thus conserving natural and scarce resources. The farming system provides a progress of money to the farmer round the year by way of disposal of eggs, edible mushroom, milk, honey, silkworm cocoons, etc. This will help a resource-poor farmer to get out of the clutches of moneylenders/agencies. Recycling of organic wastes reduces the requirement of chemical fertilizer. Further, biogas production can meet the household energy requirement. Thus, IFS goes a long way in solving energy crises (Manjunatha, 2014).

\section{REFERENCE}

[1] Ashby, J.A. (2001). Integrating research on food and the environment: An exit strategy from the rational fool syndrome in agricultural science. Ecol. Soc, 5.

[2] Beteta, T. (1996). Experiences of recycling Manure in Colombia, M.Sc. Thesis, Uppsala, Sweden.

[3] CARDI, (2010). A Mannual on Integrated Farming System. Caribbean Agricultural Research and Development Institute, (Ministry Of Economic Development, Belize), (pp.158).

[4] Dashora L.N., and Singh, H., (2014). Integrated Farming System-Need of Today. International Journal of Applied Life Sciences and Engineering 1(1), (pp. 28-37).
[5] Devendra, C. and Thomas, D. (2002). Crop-animal interactions in mixed farming systems in Asia. Agricultural Systems 71: (pp. 27-40).

[6] Edwards, P., (1997). Sustainable food production through aquaculture. Aquaculture Asia. Volume 2. School of Environment, Resources and Development, Asian Institute of Technology (AIT), Pathumthani, Thailand.

[7] FAO, (2010). Sustainable crop production intensification through an ecosystem approach and an enabling environment: capturing efficiency through ecosystem services and management, FAO Committee on Agriculture, June 16-19.

[8] Gill M.S., Samra J.S., and Singh G., (2005). Integrated farming system for realizing high productivity under shallow water-table conditions. Research bulletins, Department of Agronomy, PAU, Ludhiana,(pp. 1-29).

[9] Gupta, V., Rai, P.K. and Risam, K.S. (2012). Integrated Crop-Livestock Farming Systems: A Strategy for Resource Conservation and Environmental Sustainability. Indian Research Journal of Extension Education, Special Issue, 2: (pp. 49-54).

[10] IAASTD, (2009). Agriculture at the Crossroads, International Assessment of Agricultural Knowledge, Science and Technology for Development, Washington, DC, Island Press.

[11] Integrated Farming System - An Holistic Approach: A Review. Research and Reviews: Journal of Agriculture and Allied Sciences e-ISSN: 2319-9857 p-ISSN: 2347-226X.

[12] Jayanthi, C., (2006). Integrated farming system: A path to sustainable agriculture. 2nd edition, Published by department of Agronomy, Directorate of Soil and Crop management studies, Tamilnadu Agricultural University, Coimbatore, (pp. 1).

[13] Jitsanguan, T., (2001). Sustainable agriculture systems for small scale farmers in Thailand: implications for the environment. Available at: http://www.agnet.org/library/eb/509/ (Accessed 1 February, 2012).

[14] Lal M., Patidar J., Kumar S. and Patidar P. (2018). Different integrated farming system model for irrigated condition of India on basis of economic assessment: A case study: A review International Journal of Chemical Studies 2018; 6(4): ISSN: 2349-8528 E-ISSN: 2321-4902 (pp. 166175) 


\section{International Journal of Engineering Applied Sciences and Technology, 2020 \\ Vol. 4, Issue 9, ISSN No. 2455-2143, Pages 134-137 \\ Published Online January 2020 in IJEAST (http://www.ijeast.com)}

[15] Lal, R. and Miller, F.P. (1990). Sustainable farming for tropics. In: Singh, R.P. (Ed.) Sustainable agriculture: Issues and Prospective., Indian Society of Agronomy, IARI, New Delhi, Vol.1, (pp. 69-89).

[16] Manivannan, A., Mathialagan, P. and Narmatha, N. (2011). Goat based farming system in Tamilnadu, (pp. 163).

[17] Manjunatha, S.B., Shivmurthy, D., Sunil, A.S., Nagaraj, M.V. and Basavesha K.N. (2014). Integrated Farming System - An Holistic Approach: A Review. Research and Reviews: Journal of Agriculture and Allied Sciences e-ISSN: 2319-9857 p-ISSN: 2347-226X.

[18] Mohanty, D., Patnaik, S.C., Jeevan Das, P., Parida, N.K. and Nedunchezhiyan, M. (2010). Sustainable livelihood: a success story of a tribal farmer. Orissa Review, September: (pp. $41-43$ ).

[19] Ngambeki, D.S., Deuson, R.R. and Preckel, P.V. (1992). Integrating livestock into farming systems in northern Cameroon. Agricultural Systems, 38: (pp. 319-338).

[20] Okigbo, B.N., (1995). Major farming systems of the lowland savanna of SSA and the potential for improvement. In: Proceedings of the IITA/FAO workshop, Ibadan, Nigeria.

[21] Panke, S.K., Kadam, R.P. and Nakhate, C.S., (2010). Integrated Farming System for suatainable rural livelihood security. In: 22nd national seminar on "Role of Extension in Integrated Farming Systems for sustainable rural livelihood, 9th -10th Dec, Maharastra, (pp. 33-35).

[22] Radhamani, S., Balasubramanian, A., Ramamoorthy, K. and Geethalakshmi, V., (2003). Sustainableintegrated farming systems for dry lands: A review. Agricultural Reviews, 24: (pg 204-210).

[23] Rakocy, J.E., Masser, M.P., and Losordo, T.M. (2006). Recirculating aquaculture tank production systems: aquaponics - integrating fish and plant culture. Stoneville, MS: Southern Regional Aquaculture Center. Publication No. 454 .

[24] Rangaswamy, A., Venkatswamy, R., Premshekhar, M., Jayanthi, C. and Palaniappan, S.P. (1996). Integrated farming systems for rice based ecosystem. Madras Agricultural Journal 82(4): (pp. 290-293).

[25] Ravallion, M., Chen, S., (2007). China "es (Uneven) progress Against Poverty, Journal of Development Economics, 82(1), (pp. 1-42).

[26] Sasikala V., Tiwari R., Saravanam M. (2015). A review on integrated farming system journal of international academic research for multidisciplinary ISSN: 2320-5083, Volume 3, Issue 7 .

[27] Singh G., (2004). Farming systems options in sustainable management of national resources. In: Proceedings National Symposium on Alternative Farming Systems held at PDCSR, Modipuram, 16-18 September, (pg 80-94).

[28] Singh, K.P., Singh S.N., Kumar H., Kadian V.S. and Saxena K.K. (1993). Economic analysis of different farming systems followed on small and marginal land holdings in Haryana. Haryana Journal of Agronomy, 9: (pp. 122-125).

[29] Singh, S.N., Saxena, K.K., Singh, K.P., Kumar, H. and Kadian, V.S. (1997). Consistency in income and employment generation in various farming systems. Annals of Agricultural Research, 18(3): (pp. 40-43).

[30] Thamizoli, P.R., Rengalakshmi, K., Senthilkumar. and Selvaraju, T. (2006). Agronomic Rehabilitation and Livelihood Restoration of Tsunami Affected Lands in Nagapattinam District of Tamil Nadu. M.S. Swaminathan Research Foundation Chennai, (pp. 31).

[31] Tripathi, S.C., and Rathi, R.C. (2011). Livestock farming system module for hills. In: Souvenir. National symposium on technological interventions for sustainable agriculture, 3rd 5th May, GBPUAT, hill campus, Ranichuri, (pp. 103 -104). 